\title{
Reading from farmers' scripts: Local perceptions of climate variability and adaptations in Laikipia, Rift Valley, Kenya
}

\author{
Sarah Ayeri Ogalleh ${ }^{1,2,3} *$ and Christian $\operatorname{Vogl}^{2}$ \\ University for Natural Resources and Life Sciences \\ Michael Hauser ${ }^{1}$ \\ Centre for Training and Integrated Research in Arid and Semi Arid Lands Development (CETRAD)
}

Submitted May 10, 2012 / Revised July 3 and August 3, 2012 / Accepted September 9, 2012 / Published online March 6, 2013

Citation: Ogalleh, S. A., Vogl, C., \& Hauser, M. (2013). Reading from farmers' scripts: Local perceptions on

climate variability and adaptations in Laikipia, Rift Valley Kenya. Journal of Agriculture, Food Systems, and Community

Development, 3(2), 77-94. http://dx.doi.org/10.5304/jafscd.2013.032.004

Copyright (C) 2013 by New Leaf Associates, Inc.

\begin{abstract}
Knowledge of climate change that increases weather-related risk to agricultural production is critical for communities depending on agriculture for their livelihood. Agriculture in rural communities in Kenya is highly dependent on rainfall, which has been diminishing over time. Most scientific studies have focused on perceptions and adaptations at the local level; however, limited studies have explored local perceptions in ways that are robust, synergistic, and could have practical application to national policy. This study assesses and compares smallholder farmers' perceptions of climate variability with regard to the local knowledge they employ to measure it and adaptations they use to mitigate it. The study was conducted in Laikipia District, Kenya, with a focus on two specific sub-

${ }^{1}$ Centre for Development Research (CDR), University for Natural Resources and Life Sciences, Vienna, Austria.

${ }^{2}$ Department for Sustainable Agriculture Systems, University for Natural Resources and Life Sciences, Vienna, Austria.

${ }^{3}$ Centre for Training and Integrated Research in Arid and Semi Arid Lands Development (CETRAD), Kenya.

* Corresponding author: Sarah Ayeri Ogalleh, +43 676605 6859; sarahogalleh@gmail.com
\end{abstract}

locations: Umande and Muhonia. Qualitative datacollection methods included transect drives, informal and key informant interviews, and focus-group discussions. A content analysis of local perceptions of climatic variability was completed using ATLASti, followed by an interpretation of the results. Smallholders' climatic perceptions are measured seasonally and yearly, and are linked to observable occurrences of climatic variables, which smallholders apply to their management of agriculture and natural resources. Perceptions are similar in both sites and include reports of erratic rainfalls (locally referred to as majimbo), droughts, degradation of resources, animal and crop diseases, and a prevalence of pests. Notable differences in adaptations used by farmers exist between the two sites. Basic infrastructural inadequacies in both sites limit smallholders from adapting. We conclude that local knowledge is critical and enables smallholders to grasp and act upon microclimate variability and is therefore a source of relevant adaptation practices. Policy-makers are recommended to do ex-ante analysis of their policies and farmer needs, and tailor the policies to enhance adaptation at the farm level. 


\section{Keywords}

adaptation, agriculture, climate change, climate variability, perceptions, smallholder

\section{Introduction}

In Kenya, agriculture contributes about 25 percent of the gross domestic product (Republic of Kenya [ROK], 2001, 2007). However, agricultural production is under considerable pressure due to climate variability and change (Aubert, 2007; Downing, Ringius, Hulme, \& Waughray, 1997; Kurukulasuriya \& Mendelsohn, 2008; Lambrou \& Nelson, 2010; Mortimore \& Manvell, 2006; ROK, 2010). Climate variability refers to deviations in the mean state of the climate, e.g., the occurrence of wind and precipitation, extremes and inconsistencies, in all temporal and spatial scales beyond that of individual weather events, including short-term fluctuations that happen from year to year (Lambrou \& Piana, 2006; Ziervogel, Nyong, Osman, Conde, Cortés, \& Downing, 2006). Climate change can be defined as "alterations in the state of the climate that can be identified by fluctuations in the mean and/or variability of its properties that persist for an extended period, typically decades or longer, whether due to natural variability or because of human activity" (Intergovernmental Panel on Climate Change [IPCC], 2007a, p. 30). Climatic changes reduce agricultural productivity, which has direct consequences for rural livelihoods (Adger et al., 2007; Bryan, Deressa, Gbetibouo, \& Ringler, 2009).

Kenya has developed a National Climate Change Response Strategy (NCCRS) to tackle climate change, but it lacks a national adaptation program (Government of Kenya [GOK], 2010). Additionally, the NCCRS is neither thorough nor consistent in its stance on how smallholder farmers' views and plight will be integrated into national policies concerning climate change. This represents a paradox since the document identifies smallholders as the group that will be most affected by climate change. Yet there is evidence that climate change will affect most economic activities of the nation (GOK, 2010; Kotir, 2011). Developing countries, including Kenya, will be affected by consequences resulting from climate variability and change (Adger et al., 2007; Bunce, Rosendo, \&
Brown, 2010; IPCC, 2007a; Kurukulasuriya \& Mendelsohn, 2008; Lambrou \& Nelson, 2010). One of the reasons why Kenya will feel the consequences strongly is due to the limited adaptation capacities in prevailing smallholder agriculture (GOK, 2010). Indeed, smallholders' efforts toward natural resource management are hampered by a lack of access to credit, land, and information, making them more vulnerable to climate variability (Marenya \& Barrett, 2007). At the national level, a study by Eriksen and Lind (2009) report that economic and political structures and processes limited the local adaptive capacity to droughts through unequal allocation of resources across the regions of Kenya. Another study in South Africa and Ethiopia shows that adaptation of smallholders' agriculture was hampered by a lack of access to credit, land, and information, making farmers more vulnerable to climatic variability (Bryan et al., 2009). Additionally, rainfall unpredictability and unreliability and droughts in East Africa are expected to make farmers more vulnerable to other ecological, economic, and social shocks (Archer et al., 2010; Munang \& Nkem, 2011).

Model forecasts have been proposed to help farmers adapt to the problems associated with climatic variability and change (Alexandrov, 1999; Centella, Gutiérrez, Limia, \& Jaspe, 1999; Mearns, Rosenzweig, \& Goldberg, 1997; Mkanda, 1999; Moise \& Hudson, 2008; Motha, 2007). Quite a few details have been discussed in these and other studies with respect to farmers' perceptions and how farmers apply these perceptions in agriculture. Although some of the models in use are relevant to Kenya, the underlying data used to generate forecasts are often highly aggregated and face the challenge of being imperfect representations of reality. As different scientists build these models, these imperfect representations are likely to differ substantially (Ericksen, Thornton, Notenbaert, Cramer, Jones, \& Herrero, 2011). This has led to limited model use and application by farmers (Cabrera, Breuer, \& Hildebrand, 2006; Ziervogel, Cartwright, Tas, Adejuwon, Zermoglio, Shale, \& Smith, 2008) as climate variability patterns are highly location-specific and may vary within short distances. The smallholders' perceptions often take note of local variations in climate. Therefore, while 
we appreciate the usefulness of models for visualizing potential future outcomes and pathways as well as for evaluating options for potential adaptation to climate change, models do not adequately address and represent smallholder perceptions (Crane, 2010; Crane, Roncoli, \& Hoogenboom, 2011). Farmers often use their practical knowledge in agriculture to make informed decisions on how to respond to climatic variability (Eigenauer, 2004). Local perceptions are therefore important in generating locally applicable climate forecasts.

The concurrent rise of decentralized governance and participatory research on agriculture and natural-resource management signifies a shift where local people's perspectives on natural resource management must be taken seriously in policy development and governance (Crane, 2010). From debates in the literature on local knowledge and climate change, adaptation has been poorly represented. Even though farmers have used their local knowledge widely, it has often failed to find its way into agricultural policy (Newsham \& Thomas, 2009, 2011). Some authors have documented local knowledge as practical (Mackinson \& Nøttestad, 1998; Newsham \& Thomas, 2011). Mackinson and Nøttestad (1998) identify significant gaps between local knowledge and scientific knowledge, and they propose combining local knowledge and scientific knowledge to build a more complete understanding of climate change and variability from both perspectives. We argue that local knowledge is critical to developing feasible policies for agricultural development in times of climate change and climate variability.

Local perceptions can be instrumental in assessing microclimatic variations and ascertaining which adaptation strategies are most suitable for specific localities (Archer et al., 2010; Ogalleh, Vogl, Eitzinger, \& Hauser, 2012). For example, in Burkina Faso the corroboration of meteorological rainfall data with local farmers' perceptions of drought led to the incorporation of perceptions into agricultural drought-mitigation adaptations, resulting in the increased adaptive capacities of farmers to drought (West, Roncoli, \& Ouattara, 2008). In India, communities and researchers cooperatively and successfully integrated local meteorological assessments and predictions, based on traditional beliefs and indicators in the sky (Kanani \& Pastakia, 1999). Viability of risk mapping was tested through examination of local perceptions among Tanzanian farmers (Quinn, Huby, Kiwasila, \& Lovett, 2003). Local perceptions were used to clarify climate variability and reasons surrounding farmers' adoption of agricultural techniques to reduce dependence on rainfall (Barbier, Yacouba, Karambiri, Zoromé, \& Somé, 2009). Many authors have reported positive results from the use of local perceptions on climate change in developing and shaping adaptation strategies (Block \& Webb, 2001; Brondizio \& Moran, 2008; Bunce et al., 2010; Cabrera et al., 2006; Newsham \& Thomas, 2011; Ogalleh et al., 2012; Speranza, 2010; ). Here, we add a Kenyan case and propose how local knowledge and scientific knowledge can work together for climate change adaptation. There is empirical evidence, however, that undermines farmers' perceptions of long-term variability. For example, the study by Rao, Ndegwa, Kizito, and Oyoo, (2011) in Kenya demonstrated that farmers' perceptions did not corroborate with observed trends in rainfall, resulted in caution towards a careful interpretation of farmers' perceptions. Our main interest here is to understand perceptions and forecast their implications for smallholder agriculture. Perceptions can be beneficial for smallholders, whose understanding and application could be limited by sophisticated quantitative model outputs presented by climate-based models, which are often used for planning and decisionmaking at the national level (Crane, 2010; Ziervogel et al., 2008).

There are two research questions and associated subquestions that guide this paper: (1) Which local perceptions of smallholders on variability affecting agriculture exist: (a) what variables do smallholders recognize; (b) to which agricultural activities and natural resources do they apply their variables; and (c) how do they measure these variables; and (2) How do smallholders use their perceptions on climate variability to design adaptation measures? Addressing these research questions will contribute to a better understanding of how perceptions of climate variability can inform adaptation policy in agriculture, both locally and nationally. 
Figure 1. Map Showing the Sublocations of Umande and Muhonia in Laikipia, Kenya

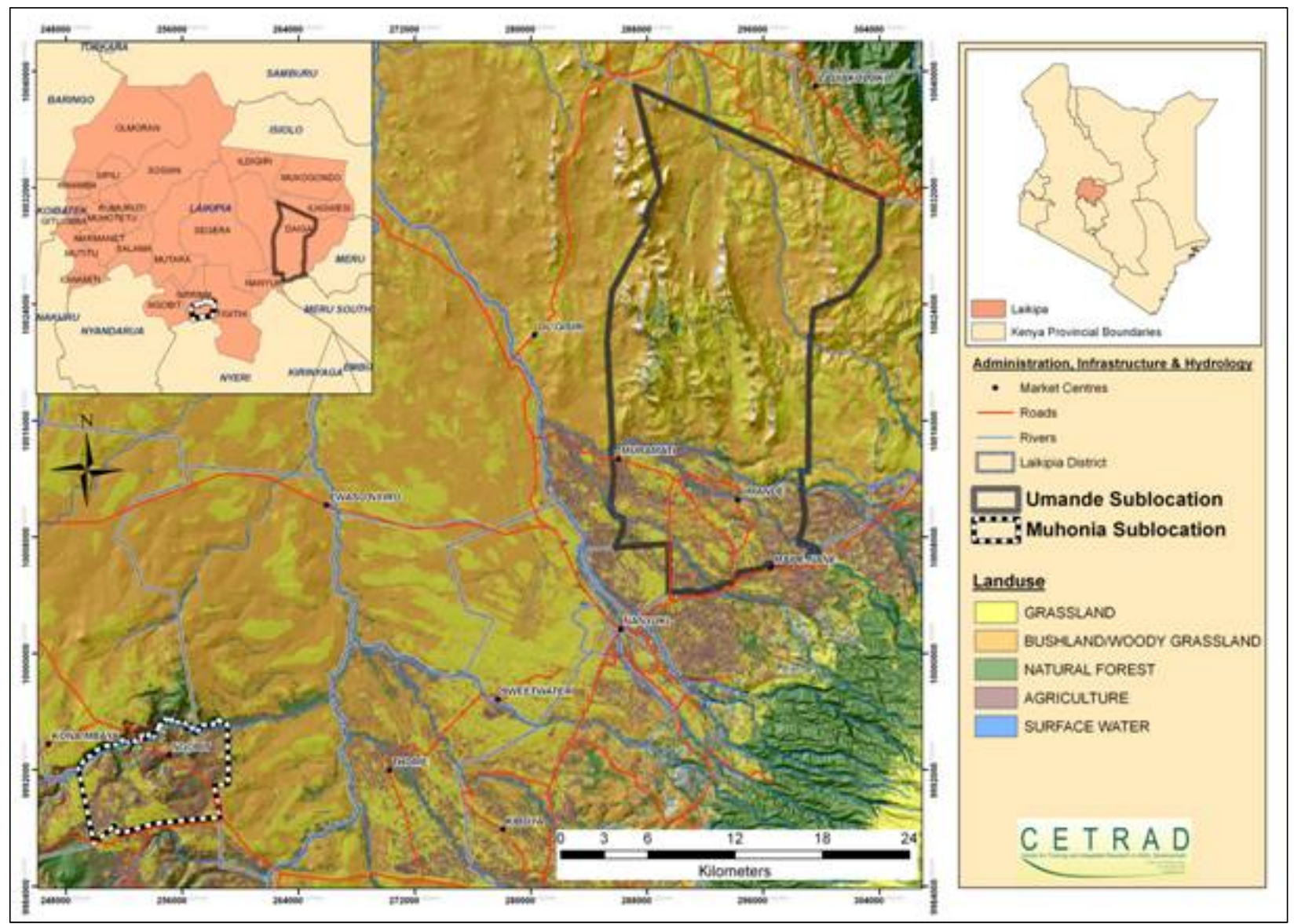

Source: Centre for Training and Integrated Research in Arid and Semi Arid Lands Development (CETRAD), 2011.

\section{Research Methods}

\section{General Overview of the Study Area}

We conducted this study in the sublocations of Umande and Muhonia, located in Kenya's Laikipia district (figure 1). Laikipia has a total area of 9,229 square $\mathrm{km}(3,563$ sq. miles) (ROK, 2008) and lies between 1,600 and 2,300 meters (5,250 to 7,550 feet) above sea level northwest of Mt. Kenya (Wiesmann, 1998). Both areas have a semi-arid climate (Wiesmann, 1998), making them ecologically fragile and susceptible to frequent droughts (ROK, 2001). We chose the district as a study site because (1) reports on the area are available; and (2) studies focusing on climate change perceptions have not recently been done in the area. Previous studies done in the region have dwelt on water resources use, water management, and conflicts
(Liniger et al., 2005; Notter, MacMillan, Viviroli, Weingartner, \& Liniger, 2007; Wiesmann, Gichuki, Kiteme, Liniger, 2000). Thus, the focus on climate change and perceptions is valid.

The population of the entire district stands at 322,187 , with a density of 35 people per $\mathrm{km}^{2}$ (91 people per mile 2 ) (ROK, 2008). Umande is approximately $20 \mathrm{~km}$ (12 miles) away from administrative town of Nanyuki, while Muhonia is roughly $70 \mathrm{~km}$ (43 miles) away. Smallholders from both sublocations have migrated from the central, densely populated highlands in search of land for agriculture and grazing land for livestock (Wiesmann, 1998).

\section{General Research Approach}

The study focused on farmers with less than 10 acres (4.0 ha) of land. With small land holdings, 
farmers have limited scope for diversifying crops in the face of climate variability (Lambrou \& Nelson, 2010). We use the term "perceptions" to include recognition and interpretation of climate variables (e.g., rainfall, temperature, frost), and application of climate variables on resources such as crops, livestock, forests, rivers. We also include recognition of droughts and deforestation that force smallholders to adjust their farming as a response to climate variability.

Data was collected using qualitative research methods (Silverman, 2005). These included transect drives complemented by participant observations, informal interviews, focus-group discussions, and interviews with key informants. Such a mixedmethod approach has already been applied in developing countries for various studies, including the assessment of human perceptions on vulnerability and resilience to climate change and multiple stressors of climate change and local knowledge (Barbier et al., 2009; Bunce et al., 2010; Crane, 2010; Newsham \& Thomas, 2011). The time frame considered (between 20 to 40 years of settlement) is suitable to account for changes with regards to climate variability (Hageback, Sundberg, Ostwald, Chen, Yun, \& Knutsson, 2005). We collected data between October 2010 and January 2011.

The language used for interviews and discussions was Kiswahili ${ }^{1}$ (spoken fluently by the first author), but where respondents preferred to converse in Kikuyu (the predominant local language in central Kenya), a local member of the village served as an interpreter with prior training by the first author. Interviews and discussions were recorded and saved as audio documents on a computer and external hard drive for later transcription. A second translator was consulted during transcribing in order to match the translations in Kikuyu and English.

\section{Data Collection}

We carried out informal interviews with purposively selected farmers as open-ended conversations on perceptions of climate change in both subloca-

\footnotetext{
${ }^{1}$ Kiswahili is one of the official languages of Kenya and is spoken in the majority of communities.
}

tions to help the researchers become familiar with the study surroundings. Owing to the large area of the two sublocations, we used a vehicle to do two transect drives in both sublocations to get an overview of the livestock and agronomic practices in the area. We jotted insights gained down in a notebook for subsequent analysis and then interpretation. The information gathered helped to triangulate information given by smallholders and provided the basis for developing a question checklist for focus-group discussions (FGDs) and key-informant interviews.

We conducted four separate FGDs with farmers in each sublocation. Participants were purposefully selected based on sublocation, time of settlement ( $\geq 20$ years), as well as their knowledge and experience in agriculture. FGDs were conducted as open discussions among participants (Cabrera et al., 2006; Silverman, 2004), providing room for communicative processes such as storytelling, arguments, challenges, and disagreement among participants that allowed them to react and build on responses of other participants. Topics of local perceptions and climate variability were introduced to the farmers for discussions. The number of participants per session ranged from six to 12 (Macchi, 2011).

Focus-group discussants helped to identify appropriate key informants, who were selected based on sublocation, age, years of settlement $(\geq 20$ years), experience in agriculture, and knowledge of local climate. A checklist of questions guided the interviews with a purposeful sample of 36 individual smallholders (18 from each sublocation), two agricultural extension officers, and one veterinary officer. The duration of each interview depended on the respondent and ranged from half an hour to one and a half hours.

\section{Data Analysis}

All interviews and FGDs were transcribed using Express Scribe software and imported into the program ATLAS-ti for qualitative analysis (Muhr \& Friese, 2004). The first author subjected 48 primary documents to content analysis based on ATLAS-ti, including all the informal interviews, FGDs, and key-informants interviews. Ex-situ coding was 
conducted. We categorized perceptions into three coding system:

1. Climatic variables, including rainfall, sun, and frost, that were later assigned to "families."

2. Applicability of climate variables on agriculture and natural resources, including droughts, crop losses, livestock losses, and migration.

3. Ways of measuring variables, including new and prevalent crop pests and diseases, and livestock pests and diseases.

Coding for the second research question was based on the use of perceptions to adapt agricultural practices to climatic variability, as well as propositions for future adaptations.

\section{Results}

The following results demonstrate the perceptions of climatic variables, their measurement, and the adaptations that follow in respondents farms.

\section{Climatic Variables}

Through frequently repeated statements and experiences, interviewees from both sublocations noted climate variability since the time they first settled, by noting changes in seasons:

When we settled, long rains came from March $15^{\text {th }}$ to April yearly, short rains came from August and September, this does not happen anymore.... Our rainfall seasons and patterns have changed. (Participant of FGD 3 Umande)

Rains used to come in April and in October. We had intermittent rains in other months of the year, now, the rains may come in April or October, and sometimes they do not come at all. (Key informant 14 Muhonia)

Therefore, rainfall patterns, seasons, and amounts constitute the farmers' observations of climate variability. In addition, interviewees equated variability to the political term majimbo ${ }^{2}$ through various expressions. Majimbo means that it rains in one neighborhood but not in another. This expression arose from the FGD and a few key informants from both sites.

The rains come in majimbo. (Participant of FGD 1, 2 Umande)

It can be raining at my neighbor's farm and I am basking in the sun. (Participant of FGD 4 Umande)

The El Niño ${ }^{3}$ we hear rained the whole of Kenya; here we never had any rains. We hear people had floods in Budalangi, ${ }^{4}$ but here there were no rains. (Participant of FGD 3 Umande)

The term majimbo was also used to depict additional erratic occurrence of frost and hailstorms:

$M b a a^{5}$ comes and destroys our crops at night; mbaa can destroy crops on my farm and does not destroy crops on my neighbor's farm. (Participant of FGD 3 Umande)

I planted tomatoes and irrigated them, then hailstorms came and destroyed the tomatoes. I have felt the effects of hailstorms twice. (Key informant 7 Umande)

Additionally, the increased duration of sunshine is what constitutes the perceptions of high temperatures and dry spells for respondents in Laikipia.

\footnotetext{
${ }^{2}$ Majimbo means national devolution into provinces, counties, districts, and wards. In the context of the informants' perceptions, it means erratic patterns of rainfalls on their farms.

${ }^{3} \mathrm{El}$ Niño is used metaphorically to show the abundance of rains in other parts of Kenya reported on television and radio broadcasts.

${ }^{4}$ Budalangi is a county in western Kenya that experiences yearly floods that displace households and destroy livestock and crops.

${ }^{5} \mathrm{Mbaa}$ is a local word for frost.
} 
Furthermore, interviewees reported changes in wind direction and intensity as indicators of climate variability. The interviewees explained that changes in wind directions entailed wind blowing from west to east, which was considered a sign of dryness, compared to wind blowing from east to west, which indicated a likelihood of some rain showers.

\section{Climate V ariables Application on Agricultural} Activities and Natural Resources

Agricultural and natural resources that farmers associate with their climate variables include trees, forests, rivers, grass, crops, and livestock.

When we settled in 1974, the rains were abundant, as years passed, rains started to diminish. Our rivers began to diminish too. (Participant of FGD 3 Muhonia)

When there are no rains, we know that we shall not have water in rivers to take us up to January to March the following year. (Participant of FGD 4 Umande)

When we settled here, there was no mbaa that scorched beans and maize; mbaa was not rampant because we had trees and grass around us, now there are no trees, and crops are targeted by mbaa. (Key informant 4 Muhonia)

Other perceptions expressed address droughts and migration as echoed in interviewees quotes:

In 1965 there was drought and we were given gathek $a^{6}$ by the government. (Key informant 7 Umande)

In March 1990, when I settled, we received lots of rains, I planted maize late that season and harvested, in October that year, I planted and I got good harvests. (Key informant 1 Umande)

${ }^{6}$ Gathek $a$ in Kikuyu means yellow maize, which was given as relief food to the local community in 1965.
The information gathered from those who have been settled for 46 years (from 1965 to 2011) and those who have been settled for 21 years (from 1990 to 2011) depicted two different climatic observations over four decades. Drought was a catastrophic stress 46 years ago, and the provision of relief food by the government demonstrated the extent of its severity. Interviewees' narratives show that drought is a problem for smallholders on one hand because it results in loss of crops and time (labor invested in failed crop production) and on the other hand because as a sign of climatic variability it interrupts farmers' ability to predict rains, as highlighted in the following quote:

For the past three years, we planted crops; when crops are about to flower, the rains stop and crops dry. We are forced to wait between eight months to one year to cultivate. (Key informant 8 Muhonia)

We used to plant the 614 maize series, now the 614 series does not do well anymore. (Participant of FGD 2 Muhonia)

We cannot predict the rains anymore. (Participant of FGD 4 Muhonia)

Women discussants perceived that men were migrating to other areas due to the droughts in order to preserve their livelihoods.

Both sites reported cases of migration, but Muhonia had more cases than Umande. There are two reasons to explain this difference: (1) proximity to water sources, and (2) proximity to the administrative town of Nanyuki. Firstly, Umande respondents have easy access to the Sirimon and Timau rivers that flow near their homes; Muhonia respondents lack access to the seasonal Karemeno and Ngobit rivers that flow far from the farmers' homes. Secondly, Umande farmers' nearness to the administrative town of Nanyuki provides an easy opportunity for those interested in making a daily commute to seek off-farm jobs, an opportunity that is not available to Muhonia farmers. The types of jobs that migrants are engaged in include shortterm jobs in other towns adjacent to the sublocations, mostly agriculture-related farm work. 
Migrants engaging in agricultural activities on other farms are paid between Kshs. 100 and 150 (equivalent to USD1.25-2.00 based on 2011 rates) for eight hours of work. In Umande, farmers who commuted to Nanyuki would be paid between Kshs. 200 and 300 (equivalent to USD2.50-3.50) for eight hours of work. Smallholders report a decrease in off-farm job opportunities in drought seasons, as there are only a few agriculture-based work opportunities, which increases the competition for available jobs. The high supply of jobseekers together with the low demand for labor during droughts could be the cause of the varying labor wages of between Kshs. 100 and 150 per day on farms.

\section{Measurement of Perception Variables}

Interviewees perceive reduced rainfall, frosts, hailstorms, temperature increases, and persistent droughts as cases of climate variability. Measures cited by interviewees focus on new diseases and the prevalence of increased occurrences of diseases. Relating to crop pests and diseases, interviewees report an increase in both livestock and crop diseases because of climatic changes.

The narratives below show the crop pests and diseases identified by interviewees:

Maize never had any diseases, but now maize is attacked by diseases such as aphids and leaf rust. Leaf rust occurs when we have a lot of heat; head $\operatorname{smut}^{7}\left(n d u t u^{8}\right)$ disease of maize, we suspect head smut came from bad seeds and increasing temperatures. Earlier, beans required no pesticides; now, you will not harvest beans without using pesticides. (Participant of FGD 4 Umande)

Aphids disappear from potatoes when it rains, but when there is no rain, aphids are vigorous in destroying crops. Minyongoro ${ }^{9}$

\footnotetext{
${ }^{7}$ A fungal infection that penetrates maize seedlings and grows inside the plant without showing symptoms until the tasseling and silking stages, causing damage to the crop.

${ }^{8} \mathrm{Ndutu}$ in Kikuyu means head smut disease.

${ }^{9}$ Minyongoro in Kikuyu means millipedes.
}

attack our potatoes nowadays; we never saw minyongoro eat potatoes like they do now. (Participant of FGD 4 Umande)

Interviewees suspect ticks in livestock to be the cause of a new disease called heartwater.

We have witnessed heartwater disease since 2000 , five years ago; I lost most of my livestock to heartwater. (Key informant 18 Muhonia)

Interviewees link climatic variables to their crops and livestock. The measurements of climatic variables of rainfalls, temperature increase, and droughts are in the form of observable spread of diseases. Differences in the distribution of diseases in the two sites can be seen. Umande reports millipedes, leaf rust, and head smut. Muhonia reports millipedes, leaf rust, and head smut as well as rats and the heartwater disease in livestock. The difference could lie in Umande's proximity to the town of Nanyuki. Umande respondents could easily access pesticides and medication from agrovet ${ }^{10}$ shops. Muhonia may have limited access to these services because of their distance from Nanyuki. From participant observation, there was one agrovet shop in Umande, whereas Muhonia had no such shop.

\section{Farmer Adaptations and Preferred Adaptation Strategies}

Farmers use their climate variability knowledge to choose and design their adaptation strategies, as highlighted in the following statements:

Because of the rains, we plant maize, beans and potatoes, we mix long- and short-season crops. When we have long rains, we harvest the long-season varieties and short-season varieties with little rains. (Participant of FGD 1 Umande)

\footnotetext{
${ }^{10}$ Shops that sell agro-chemicals and livestock feed and medication.
} 
In addition to the long- and short-season crops, additional adaptations linked to rainfall variability included making small water basins around crops to preserve water for the crops.

Respondents have adapted to climatic variables through mixing and intercropping of both shortand long-series crops to maximize any available rains. Most farmers grew both long- and shortseason crops. For example, they planted the sixseries ${ }^{11}$ maize seeds varieties $(614,625,628)$ and five-series $^{12}(511,512,513$, DHO4) when they settled in the area and are still doing the same after 20 to 40 years of settlement. Intercropping of the long-series and short-series hybrids is done in response to rainfall unreliability. Umande respondents report the use of pesticides to control pests and diseases in crops. Making small basins around every crop was more prominent in Umande than in Muhonia.

Other adaptations identified included early planting to maximize on any little rains. However, some farmers opted for late planting citing various reasons, as shown in the statement below:

Some farmers plant early and then the rains come in little amounts and the seeds get destroyed in the soils. I plant later when I think rains are plenty and this means at least three consecutive days of raining. (Key informant 3 Muhonia)

From these narratives, we deduce that interviewees adapt based on their perceptions.

In Umande, due to their access to river water, farmers temporarily migrated to riverbanks to cultivate, where only commercial crops such as tomatoes, snow peas, and cabbages are grown. Muhonia farmers would have opted to migrate to riverbanks, but the enormous distances to the Karemeno and Ngobit Rivers are a discouragement.

\footnotetext{
${ }^{11}$ Six-series varieties take from 6 to 9 months to mature - a long time.

${ }^{12}$ Five-series varieties take shorter periods (4 to 6 months) to mature.
}

Discussants and informants from both sublocations identify water as a primary solution to adapt to climate variability and change. In this case, dam construction on rivers was proposed as a way to mitigate water scarcity during drought seasons. An additional proposition from a respondent in a FGD was as follows:

If the government brings us water, we can tap it to our homes and irrigate crops.

(Participant of FGD 3 Muhonia)

Interviewees identify water as the main problem and propose the construction of water pans on individual farms and big dams to supply water during dry seasons. The interviewees emphasize that the government should provide water for domestic and agriculture. We deduce a lack of basic infrastructural services for the provision of water. Discussants revealed that Muhonia residents depended on the currently nonfunctioning Mutitu water project for their supply of water in former times. In Umande, participants currently depend on the functioning Muoroga water project for their supply of domestic water, although the amount is rationed. A number of farmers in Umande constructed small water pans to store the rationed water for later use. Only two farmers in Muhonia had water pans.

\section{Discussions}

\section{Local Perceptions}

Farmers use occurrences in their environments to deduce climate-related phenomena (Jones, Hansen, Royce, \& Messina, 2000; Ogalleh et al., 2012; Vedwan \& Rhoades, 2001; Winarto, Stigter, Anantasari, Prahara, \& Kristiyanto, 2010). The interviewees have a baseline reference point for perceptions: the period from earlier settlements to the present time. Climate variables are measured through observation of yearly rainfall seasons, rainfall amounts, and scorching sun. Similar findings have been reported in India (Kanani \& Pastakia, 1999). Our findings are similar to the case of farmers along marginal African coasts and the Limpopo basin who perceived temperature rise, breaks in rainy seasons, and erratic rainfalls as 
stressors on livelihood (Gbetibouo, 2009; Howden, Soussana, Tubiello, Chhetri, Dunlop, \& Meinke, 2007; Meinke, Howden, Struik, Nelson, Rodriguez, \& Chapman, 2009; United Nations Development Program [UNDP], 2007). Interviewees repeatedly state that rainfall patterns and amounts are key indicators of climatic variability because of crop yields and livestock production that are dependent on rainfall. These findings are consistent with Berger (1989); Haile (2005); Lobell and Burke (2008); and Mortimore (1989) in Laikipia, Ethiopia, Africa and West Africa, respectively. Interviewees' knowledge of rainfall patterns conform to findings reported by Berger (1989) and Kilavi (2010), where long rains come annually from March 1 to June 15 and short rains from September 16 to December 31. Interviewees additionally noted that the rainfall patterns and seasons no longer apply and claim that seasons have shifted to later dates after April of every year, findings that concur with the meteorological predictions for Laikipia district in the year 2011, where "depressed and delayed rainfalls" (ROK, 2011, p. 25) were reported. Additionally, our results demonstrate respondents' abilities to predict rain occurrences through observation of changes in the wind direction. Our findings on wind collaborate with studies done in Tigray, Ethiopia (Mengistu, 2011). The emphasis placed on rainfall in both sublocations points to the need for policy on adaptation to focus on interventions that will increase water availability for agriculture.

Majimbo, constantly mentioned by respondents, bears double meaning. First, it describes the erratic rainfalls experienced within each sublocation, in comparison to other areas in Kenya. Interviewees depict differences between their sublocations and other parts of Kenya, associated with El Niño occurrences that did not occur historically in their sublocations. We interpret further that farmers have additional networks that inform their perceptions beyond their subjective observations. Secondly, the use of the term majimbo in both sites implies differences in precipitation between and within sublocations. Majimbo could also mean an area that is "disadvantaged" due to climate variability compared to the other regions of Kenya, which we equate to the political concept of decentralization. This may imply that climatic variability solutions aiming at smallholders should be decentralized. Majimbo can also be interpreted in terms of an allocation of resources that could increase or limit which adaptations interviewees take to counteract climatic variability. Our interpretation is comparable to insights and conclusions by Eriksen and Lind (2009), that the unequal allocation of resources have effects on adaptation capacities of pastoralists and smallholders in the Kitui and Turkana districts of Kenya. When focusing on perceptions, Umande and Muhonia respondents have proved that climate variability patterns are highly location-specific and vary within short distances, and that overall predictions of climate may not necessarily produce benefits for these interviewees. Therefore, the notion that the ability to better predict climate will automatically produce benefits for diverse user groups (Messina, Hansen, \& Hall, 1999) is refuted by our findings. In addition, focusing on local perceptions is rewarding because local knowledge is one way that farmers respond to the complexities of nature, and if ignored, then local people's knowledge of this complexity of their environment is lost. Because interviewees use their local knowledge to grasp and act upon microclimate variability, local knowledge can be a source of relevant agricultural practices.

Interviewees incur major losses in crops and livestock because of climatic variability. Droughts are a potential risk and source of losses in agricultural production (Ericksen et al., 2011; UNDP, 2007; World Bank, 2007). An increase in the frequency of droughts in the region leads to decreased agricultural production and, in the worst-case scenario, can force marginal agriculture out of production (Conway, 2009; IPCC, 2007b; Kotir, 2011; Mude, Ouma, van de Steeg, Kariuki, Opiyo, \& Tipilda, 2007). Frequent droughts could mean severe challenges for Umande and Muhonia in the future. It is urgent that we use interviewees' knowledge to address the problem of droughts because (1) drought perceptions mirror interviewees' needs for specific policy and planning for interventions that enhance local agriculture; and (2) with or without droughts, agriculture constitutes the main source of livelihood for these interviewees. 
Temporal migration transforms drought risks to opportunities in the form of employment elsewhere (Paavola, 2008; Smucker \& Wisner, 2008). Our results agree with those of farmers in Tharaka Nithi (Kenya) and Morogoro (Tanzania), where migration and employment reduced farmers' drought risks (Paavola, 2008; Smucker \& Wisner, 2008). However, there are differences in remuneration for off-farm activity in both sublocations: Umande is advantaged in getting higher wages because of its proximity to Nanyuki town, while Muhonia is more isolated and interviewees cannot access Nanyuki regularly. Proximity to urban centers increases benefits to rural communities, such as in the case of the lowlands of West Africa (Erenstein, 2006) and Nepal (Ghimire, Shivakoti, \& Perret, 2010). Highly vulnerable farmers had limited access to market centers and low employment diversification. Agricultural farm wages constitute a major source of off-farm employment (Ghimire et al., 2010). Interviewees' labor wages of less than two dollars is insufficient to fulfill the basic daily needs considering soaring food prices in 2008, and recently in 2011, making it even more difficult for households to fulfill their basic needs (Munang \& Nkem, 2011). We consider the migration of men during droughts a disadvantageous off-farm activity that may increase households' vulnerability to drought, when there are hardly any rains and fewer paid agricultural opportunities (Winarto, Stigter, Prahara, Anantasari, \& Kristiyanto, 2011). Our argument underline conclusions of Mendelsohn, Basist, Kurukulasuriya, and Dinar (2007) that climate change will worsen and lower the incomes and opportunities of the most vulnerable populations.

Agricultural and natural resources (forests, rivers, land) represent important linkages to interviewees' perceptions. Umande and Muhonia respondents base their observations on a comparative reference point: their observations from when they settled and what is currently happening. The applicability of perceptions happens in terms of subjective observations of volumes in rivers, which are conducted randomly based on rainfall patterns and seasons. Interviewees use their observations to determine how much water will be available for their use during the year. This knowledge is what farmers use for decision making in their agricultural practice, and therefore scientists can use this knowledge to understand farmers' decision-making processes and applicability of adaptations in order to support appropriate adaptations befitting the local communities.

Interviewees know of the cause-and-effect relationship linked to frost and its effects on trees and crops. In these relationships, they acknowledge the value of trees in shielding their crops from frost. The narratives showed that interviewees' respective sublocations had been deforested, consequently reducing the number of trees in comparison to when they settled. Poor families aim to meet their short-term needs by harvesting the local natural resources, e.g., cutting trees for firewood and charcoal and depleting soil nutrients. Similar results were reported in the Sudano-Sahelian zone (Wardell, Reenberg, \& Tøttrup, 2003). Cutting down trees results in deforestation, which contributes to greenhouse gas (GHG) formation. GHGs lead to global warming, and global warming leads to increased droughts and less rainfall, among other impacts of climate change (Conway, 2009). The applicability of variables on agriculture and natural resources in Umande and Muhonia is a relevant indicator of the need for policies that aim to mitigate climate change by, for example, reducing deforestation and increasing tree cover.

Interviewees attributed the growths in pests to temperature increases. However, interviewees are not able to distinguish between diseases and pests. Based on their subjective measurements relying on previous and current observations, interviewees measure diseases and pests in terms of prevalence and identify cause-and-effect relationships based on their observations of livestock and crop losses. Increased ticks resulted in more widespread disease and emergence of diseases not witnessed before. Interviewees' sentiments on emerging new diseases can be related to insights that diseases carried by insects and other vectors could be susceptible to the effects of climate variability and change (Conway, 2009). Under climate change, pests associated with specific crops may become more active (IPCC, 1995). Increasing temperatures and decreasing water availability due to climate change will increase the burden of some diseases that will 
affect livestock and crops (IPCC, 2007a). Our findings corroborate the cases of farmers in the Sahel region (Mertz, Mbow, Reenberg, \& Diouf, 2009). Warmer temperatures speed up development rates of some insect species, resulting in a shorter time span between generations (IPCC, 1995). Some insect populations may become established and thrive earlier in the growing season, during more vulnerable crop stages. Reports by interviewees of increases in pests and rodents corroborate the IPCC reports (IPCC, 2001, 2007a). The heartwater disease in livestock is the most or second-most important tick-borne disease in Africa and has economic significance (Provost $\&$ Bezuidenhout, 1987). Interviewees use pesticides to curb the increasing prevalence of diseases and pests. We consider pesticide use an adaptation. However, interviewees' competition with pests over their crops and livestock may lead to the possibility of zoonotic diseases, and requires further research to explore the practicability of perceptions and pests and disease control in livestock and crops.

\section{Interviewees' Adaptations}

Agriculture is sensitive to weather- and climaterelated phenomena (Molua, 2002; Mude et al., 2007). Perceptions are what inform the adaptations made by interviewees. Interviewees opt to plant early in order to take advantage of little rain, while others wait for it to rain for a couple of days before they commence their plantings. Intercropping is an important adaptation for interviewees where longseries and short-series crops dominate their land. They also integrate livestock-keeping. Our findings concur with those of Nepalese farmers (Ghimire et al., 2010) and studies from 10 African countries from West Africa (Niger, Burkina Faso, Senegal and Ghana); from Central Africa (Cameroon); from East Africa (Kenya and Ethiopia); from Southern Africa (South Africa and Zambia) and from North Africa (Egypt) (Seo, 2010) where integrated farms increased in comparison to crop farming only under climate predictions for 2060. In addition, the simultaneous use of various hybrids on interviewees' farms is considered an adaptation. In this case, the long-series and short-series varieties help to strengthen resilience to impacts associ- ated with erratic rainfall, with the potential for increased harvesting during wetter seasons. In one way, our findings concur with Newsham and Thomas (2011), who reported that early-maturing crops in Namibia strengthened resilience against drier conditions. In addition to the early-maturing (short-season) crops, Muhonia and Umande farmers cultivate long-series (late-maturing) crops at the same time in order to take advantage of rains. Umande interviewees - in contrast to those in Muhonia - used water pans to store water for drought seasons. Based on perceptions, adaptations, and propositions, we interpret that adaptations are no longer "one size fits it all." Smallholder agriculture requires that specific needs and resources are tailored to interviewees' perceptions, since adaptations that work well in other parts of the country will not necessarily suit the interviewees of Umande and Muhonia. This study's framework is thus instrumental to conveying smallholders' most urgent interests for adaptations to policymakers and decision-makers.

\section{Conclusions}

In general, interviewees have an extensive capacity to carry out local prognoses of microclimate conditions. Perceptions of erratic rainfall, drought, frost, and temperature, and an increase in crop and livestock diseases in Laikipia district, are likely to increase further under climate change. The fact that local perceptions can alter over time based on environmental changes and thus cannot be used for long-term planning means that perceptions and national policies could easily complement each other. Local perceptions have the potential to support existing policies to enhance their benefits to smallholder agriculture. Since interviewees are knowledgeable about the measurements and applicability of their identified climatic variables and use their perceptions for adaptations, local perceptions can be useful for understanding local farmers' early forecasts and their adaptations to climate variability. Location-specific policies that integrate local perceptions can be the best climate adaptation investments to help vulnerable smallholders. Since policy-makers use climatic models to determine adaptation options at national levels, they could use perceptions to pinpoint the exact 
adaptations required by smallholders at local levels by doing ex-ante analysis of their policies.

Finally, a smallholder-centered approach using qualitative methods allows researchers to ground direction for policy and planning in smallholder agriculture. Interviewees' perceptions are critical to present model outcomes of local-based knowledge if national policies and plans are to work for smallholders; this could be applied, for example, to a national policy recommendation to increase irrigation at the farm level (GOK, 2010). An interviewee might recognize the adaptation as good enough for commercial purposes but may not be able to make the change because it is not economically or financially feasible. Furthermore, the adaptation may not work where limited water infrastructure exists, as in the case of Muhonia. Therefore, local knowledge can be a reliable source of relevant practices and policies.

\section{Acknowledgements}

The authors gratefully acknowledge the communities of Umande and Muhonia for their time, kindness, and cooperation throughout the data collection process; special thanks to the late SubChief Mureithi (Muhonia) and to Sub-Chief Alice Mbogo (Umande). Thanks are also due to Dominic Wahome and James Githui, who served as local translators in Umande and Muhonia, respectively. We acknowledge colleagues at the Centre for Development Research and Centre for Training and Integrated Research in Arid and Semi Arid Lands Development (CETRAD) for their comments on earlier versions of this article, translation, and production of the map of the study site. We acknowledge David Kimathi for support in organization and data collection. We acknowledge the Austrian Partnership Programme in Higher Education \& Research for Development (APPEAR) and Volkswagen Foundation for financial support, and the Department for Sustainable Agriculture Systems, CETRAD, for the logistical support provided for this study. We also acknowledge the useful comments of two anonymous JAFSCD reviewers of this article.

\section{References}

Adger, W. N., Agrawala, S., Mirza, M. M. Q., Conde, C., O'Brien, K., Pulhin, J., et al. (2007). Assessment of adaptation practices, options, constraints and capacity. Contribution of Working Group II to the Fourth Assessment Report of the Intergovernmental Panel on Climate Change (IPCC). Cambridge, UK: Cambridge University Press.

Alexandrov, V. (1999). Vulnerability and adaptation of agronomic systems in Bulgaria. Climate Research, 12(2-3 Spec. Iss. 6), 161-173. http://dx.doi.org/10.3354/cr012161

Archer, E., Bekele, T., Kassa, H., Kassa, K., Koelle, B., Lotter, D., Oettle, N.,...Ziervogel, G. (2010). Developing adaptive management strategies by small-scale farmers in semi-arid South Africa and Ethiopia under changing climatic and policy conditions. Book of Abstracts of the 2010 grantees meeting within the Volkswagen Foundation Africa Initiative, Natural Resources Research in Africa (pp. 100-105). Witzenhausen, Germany: DITSL GmbH.

Aubert, C. (2007, May). Can organic farming mitigate the impact of agriculture on global warming? Paper presented at the International Conference on Organic Agriculture and Food Security, Food and Agriculture Organization [FAO] of the United Nations, Rome.

Barbier, B., Yacouba, H., Karambiri, H., Zoromé, M., \& Somé, B. (2009). Human vulnerability to climate variability in the Sahel: Farmers' adaptation strategies in Northern Burkina Faso. Environmental Management, 43(5), 790-803. http://dx.doi.org/10.1007/s00267-008-9237-9

Berger, P. (1989). Rainfall and agroclimatology of the Laikipia Plateau, Kenya (Vol. A7). Bern, Switzerland: Geographica Bernensia.

Block, S., \& Webb, P. (2001). The dynamics of livelihood diversification in post-famine Ethiopia. Food Policy, 26(4), 333-350. http://dx.doi.org/ 10.1016/S0306-9192(01)00015-X

Brondizio, E. S., \& Moran, E. F (2008). Human dimensions of climate change: The vulnerability of small farmers in the Amazon. Pbilosophical Transactions of the Royal Society B: Biological Sciences, 363(1498), 1803-1809. http://dx.doi.org/10.1098/rstb.2007.0025 
Bryan, E., Deressa, T. T., Gbetibouo, G. A., \& Ringler, C. (2009). Adaptation to climate change in Ethiopia and South Africa: Options and constraints. Environmental Science and Policy, 12(4), 413-426. http://dx.doi.org/10.1016/i.envsci.2008.11.002

Bunce, M., Rosendo, S., \& Brown, K. (2010). Perceptions of climate change, multiple stressors and livelihoods on marginal African coasts. Environment, Development and Sustainability, 12(3), 407-440. http://dx.doi.org/10.1007/s10668-0099203-6

Cabrera, V. E., Breuer, N. E, \& Hildebrand, P. E. (2006). North Florida dairy farmer perceptions toward the use of seasonal climate forecast technology. Climatic Change, 78(2-4), 479-491. http://dx.doi.org/10.1007/s10584-006-9053-2

Centella, A., Gutiérrez, T., Limia, M., \& Jaspe, R. R. (1999). Climate change scenarios for impact assessment in Cuba. Climate Research, 12(2-3 Special Issue 6), 223-230. http://dx.doi.org/10.3354/cr012223

Conway, G. (2009). The science of climate change in Africa: Impacts and adaptation. London: Grantham Institute for Climate Change Discussion Paper.

Crane, T. A. (2010). Of models and meanings: Cultural resilience in social-ecological systems. Ecology and Society, 15(4), 19.

Crane, T. A, Roncoli, C., \& Hoogenboom, G. (2011). Adaptation to climate change and climate variability: The importance of understanding agriculture as performance. Wageningen Journal of Life Sciences, 57(3-4), 179-185. http://dx.doi.org/10.1016/j.njas.2010.11.002

Downing, T., Ringius, L., Hulme, M., \& Waughray, D. (1997). Adapting to climate change in Africa. Mitigation and Adaptation Strategies for Global Change, 2(1), 19-44.

http://dx.doi.org/10.1007/BF02437055

Eigenauer, J. D. (2004). Summary of Seeing Like a State. Bakersfield, California: Author.

Erenstein, O. (2006). Intensification or extensification? Factors affecting technology use in peri-urban lowlands along an agro-ecological gradient in West Africa. Agricultural Systems, 90(1-3), 132-158. http://dx.doi.org/10.1016/j.agsy.2005.12.005
Eriksen, S., \& Lind, J. (2009). Adaptation as a political process: Adjusting to drought and conflict in Kenya's Drylands. Environmental Management, 43(5), 817-835. http://dx.doi.org/10.1007/s00267-0089189-0

Ericksen, P., Thornton, P., Notenbaert, A., Cramer, L., Jones, P., \& Herrero, M. (2011). Mapping hotspots of climate change and food insecurity in the global tropics (CCAFS Report No. 5, pp. 1-29). Copenhagen, Denmark: CGIAR Research Program on Climate Change, Agriculture and Food Security (CCAFS). Available online at http://www.ccafs.coiar.org

Gbetibouo, G. A (2009). Understanding farmers'perceptions and adaptations to climate change and variability: The case of the Limpopo basin, South Africa (IFPRI Discussion Paper 00849). Washington, D.C.: International Food Policy Research Institute (IFPRI). Retrieved from http://www.ifpri.org

Ghimire, Y. N., Shivakoti, G. P., \& Perret, S. R. (2010). Household-level vulnerability to drought in hill agriculture of Nepal: Implications for adaptation planning. International Journal of Sustainable Development and World Ecology, 17(3), 225-230. http://dx.doi.org/10.1080/13504501003737500

Government of Kenya [GOK]. (2010). National climate change response strategy. Ministry of Environment and Mineral Resources, Government of Kenya (GOK). Hageback, J., Sundberg, J., Ostwald, M., Chen, D., Yun, X., \& Knutsson, P. (2005). Climate variability and land-use change in Danangou watershed, China: Examples of small-scale farmers' adaptation. Climatic Change, 72(1-2), 189-212. http://dx.doi.org/10.1007/s10584-005-5384-7

Haile, M. (2005). Weather patterns, food security and humanitarian response in sub-Saharan Africa. Philosophical Transactions of the Royal Society B: Biological Sciences, 360(1463), 2169-2182. http://dx.doi.org/10.1098/rstb.2005.1746

Howden, S. M., Soussana, J. F., Tubiello, F. N., Chhetri, N., Dunlop, M., \& Meinke, H. (2007). Adapting agriculture to climate change. Proceedings of the National Academy of Sciences of the United States of America, 104(50), 19691-19696. http://dx.doi.org/10.1073/pnas.0701890104 
Intergovernmental Panel on Climate Change [IPCC]. (1995). Climate Change 1995: Impacts, adaptations and mitigation of climate change: Scientific-technical analyses (Contribution of Working Group II to the Second Assessment Report of the Intergovernmental Panel on Climate Change) [R. T. Watson, M. C. Zinyowera, \& R. H. Moss. H (Eds.)]. Cambridge, UK: Cambridge University Press.

IPCC. (2001). Climate Change 2001: The scientific basis (Contribution of Working Group I to the Third Assessment Report of the Intergovernmental Panel on Climate Change) J. T. Houghton, Y. Ding, D. J. Griggs, M. Noguer, P. J. van der Linden, X. Dai, K. Maskell, \& C. A. Johnson (Eds.)]. Cambridge, UK: Cambridge University Press.

IPCC. (2007a). Climate Change 2007: Synthesis Report (Contribution of Working Groups I, II and III to the Fourth assessment report of the Intergovernmental Panel on Climate Change) [Core Writing Team: R. K. Pachauri, \& A. Reisinger (Eds.)]. Geneva: Author.

IPCC. (2007b). Climate Change 2007: The Physical Science Basis: Summary for Policymakers (Working Group I Contribution to the Fourth Assessment Report of the Intergovernmental Panel on Climate Change) [S. Solomon, D. Qin, M. Manning, Z. Chen, M. Marquis, K. B. Averyt, M. Tignor \& H. L. Miller (Eds.)]. Cambridge and New York: Cambridge University Press.

Jones, J. W., Hansen, J. W., Royce, F. S., \& Messina, C. D. (2000). Potential benefits of climate forecasting to agriculture. Agriculture, Ecosystems and Environment, 82(1-3), 169-184. http://dx.doi.org/10.1016/S0167-8809(00)00225-5

Kanani, P. R., \& Pastakia, A. (1999). Everything is written in the sky! Participatory meteorological assessment and prediction based on traditional beliefs and indicators in Saurashtra. Eubios Journal of Asian and International Bioethics, (9), 170-176.

Kilavi, M. (2010). Understanding the rain. Bulletin of the Kenya Meteorological Society.

Kotir, J. H. (2011). Climate change and variability in sub-Saharan Africa: A review of current and future trends and impacts on agriculture and food security. Environment, Development and Sustainability, 13(3), 587-605. http://dx.doi.org/10.1007/s10668-010$\underline{9278-0}$
Kurukulasuriya, P., \& Mendelsohn, R. (2008). How will climate change shift agro-ecological zones and impact African agriculture? (Policy Research Working Paper 4717). The World Bank Development Research Group, Sustainable Rural and Urban Development Team. Retrieved from http://www.worldbank.org

Lambrou, Y., \& Nelson, S. (2010). Farmers in a changing climate: Does gender matter? Rome: FAO.

Lambrou, Y., \& Piana, G. (2006). Gender: The missing component of the response to climate change. Rome: FAO.

Liniger, H., Gikonyo. J., Kiteme, B., \& Wiesmann, U. (2005). Assessing and managing scarce tropical mountain water resources: The case of Mount Kenya and the semiarid Upper Ewaso Ng'iro Basin. Mountain Research and Development, 25(2), 163-173. http://dx.doi.org/10.1659/0276-4741(2005) 025\%5B0163:AAMSTM\%5D2.0.CO;2

Lobell, D. B., \& Burke, M. B. (2008). Why are agricultural impacts of climate change so uncertain? The importance of temperature relative to precipitation. Environmental Research Letters, 3(3), 1-8. http://dx.doi.org/10.1088/1748-9326/3/3/034007

Macchi, M. (2011). Framework for community-based climate vulnerability and capacity assessment in mountain areas. Kathmandu: International Centre for Integrated Mountain Development (ICIMOD). Retrieved from http://www.icimod.org

Mackinson, S., \& Nøttestad, L. (1998). Combining local and scientific knowledge. Reviews in Fish Biology and Fisheries, 8(4), 481-490.

Marenya, P. P., \& Barrett, C. B. (2007). Household-level determinants of adoption of improved natural resources management practices among smallholder farmers in western Kenya. Food Policy, 32, 515-536. http://dx.doi.org/10.1016/i.foodpol.2006.10.002

Mearns, L. O., Rosenzweig, C., \& Goldberg, R. (1997). Mean and variance change in climate scenarios: Methods, agricultural applications and measures of uncertainty. Climatic Change, 35(4), 367-396. http://dx.doi.org/10.1023/A:1005358130291 Meinke, H., Howden, S. M., Struik, P. C., Nelson, R., Rodriguez, D., \& Chapman, S. C. (2009). Adaptation science for agriculture and natural resource management: Urgency and theoretical basis. Current Opinion in Environmental Sustainability, 1(1), 69-76. http://dx.doi.org/10.1016/j.cosust.2009.07.007 
Mendelsohn, R., Basist, A., Kurukulasuriya, P., \& Dinar, A. (2007). Climate and rural income. Climatic Change, 81(1), 101-118. http://dx.doi.org/10.1007/s10584005-9010-5

Mengistu, D. K. (2011). Farmers' perception and knowledge of climate change and their coping strategies to the related hazards: Case study from Adiha, central Tigray, Ethiopia. Agricultural Sciences, 2(2), 138-145.

http://dx.doi.org/10.4236/as.2011.22020

Mertz, O., Mbow, C., Reenberg, A., \& Diouf, A. (2009). Farmers' perceptions of climate change and agricultural adaptation strategies in rural Sahel. Environmental Management, 43(5), 804-816. http://dx.doi.org/10.1007/s00267-008-9197-0

Messina, C. D., Hansen, J. W., \& Hall, A. J. (1999). Land allocation conditioned on El Nino-Southern Oscillation phases in the Pampas of Argentina. Agricultural Systems, 60(3), 197-212. http://dx.doi.org/10.1016/S0308-521X(99) 00032-3

Mkanda, F. X. (1999). Drought as an analogue climate change scenario for prediction of potential impacts on Malawi's wildlife habitats. Climate Research, 12(23 Spec. Iss. 6), 215-222. http://dx.doi.org/10.3354/cr012215

Moise, A. F., \& Hudson, D. A. (2008). Probabilistic predictions of climate change for Australia and southern Africa using the reliability ensemble average of IPCC CMIP3 model simulations. Journal of Geophysical Research D: Atmospheres, 113(D15), 2156-2202. http://dx.doi.org/10.1029/2007JD009250

Molua, E. L. (2002). Climate variability, vulnerability and effectiveness of farm-level adaptation options: The challenges and implications for food security in southwestern Cameroon. Environment and Development Economics, 7(3), 529-545. http://dx.doi.org/10.1017/S1355770X02000311

Mortimore, M. (1989). Adapting to drought: Farmers, famines and desertification in West Africa. New York: Press Syndicate, University of Cambridge. http://dx.doi.org/10.1017/CBO9780511720772

Mortimore, M., \& Manvell, A. (2006). Climate change: Enhancing adaptive capacity (NRSP Brief). Hemel Hempstead, UK: UK Department for International Development (DFID)- Natural Resources Systems
Programme (NRSP). Retrieved from http://www.nrsp.org.uk

Motha, R. P. (2007). Implications of climate change on long-lead forecasting and global agriculture. Australian Journal of Agricultural Research, 58(10), 939944. http://dx.doi.org/10.1071/AR06104

Mude, A., Ouma, R., van de Steeg, J., Kariuki, J., Opiyo, D., \& Tipilda, A. (2007). Kenya adaptation to climate change in the arid land: Anticipating, adapting to and coping with climate risks in Kenya - Operational recommendations for Kenya Adaptation to Climate Change in Arid Lands (KACCAL). Nairobi: International Livestock Research Institute (ILRI).

Muhr, T., \& Friese, S. (2004). ATL AS.ti, The knowledge workbench: User's guide and reference (Second Ed.). Berlin: ATLAS.ti Scientific Software Development $\mathrm{GmbH}$.

Munang, R., \& Nkem, J. N. (2011). Using small-scale adaptation actions to address the food crisis in the Horn of Africa: Going beyond food aid and cash transfers. Sustainability, 3(9), 1510-1516. http://dx.doi.org/10.3390/su3091510

Newsham, A., \& Thomas, D. (2009). Agricultural adaptation, local knowledge and livelihoods diversification in North-Central Namibia (Tyndall working Paper 140). Norwich, UK: Tyndall Centre for Climate Change Research. Retrieved from http://www.tyndall.ac.uk

Newsham, A. J., \& Thomas, D. S. G. (2011). Knowing, farming and climate change adaptation in NorthCentral Namibia. Global Environmental Change, 21, 761-770. http://dx.doi.org/10.1016/j.gloenvcha.2010.12.003

Notter, B., MacMillan, L., Viviroli, D., Weingartner, R., \& Liniger, H.-P. (2007). Impacts of environmental change on water resources in the Mt. Kenya region. Journal of Hydrology, 343(3-4), 266-278.

Ogalleh, A. S., Vogl, C. R., Eitzinger, J., \& Hauser, M. (2012). Local perceptions and responses to climate change and variability: The case of Laikipia District, Kenya. Sustainability, 4(12), 3302-3325. http://dx.doi.org/10.3390/su4123302

Paavola, J. (2008). Livelihoods, vulnerability and adaptation to climate change in Morogoro, Tanzania. Environmental Science \& Policy, 11(7), 642-654. http://dx.doi.org/10.1016/j.envsci.2008.06.002 
Provost, A., \& Bezuidenhout, J. D. (1987). The historical background and global importance of heartwater. The Onderstepoort Journal of Veterinary Research, 54(3), 165-169.

Quinn, C. H., Huby, M., Kiwasila, H., \& Lovett, J. C. (2003). Local perceptions of risk to livelihood in semi-arid Tanzania. Journal of Environmental Management, 68(2), 111-119. http://dx.doi.org/10.1016/S0301-4797(03)00013-6

Rao, K. P. C., Ndegwa, W. G., Kizito, K., \& Oyoo, A. (2011). Climate variability and change: Farmer perceptions and understanding of intra-seasonal variability in rainfall and associated risk in semi-arid Kenya. Experimental Agriculture, 47(2), 267-291. http://dx.doi.org/10.1017/S0014479710000918

Republic of Kenya [ROK]. (2001). National development plan 2002-2008. Nairobi: Republic of Kenya, Ministry for Planning.

ROK. (2007). National policy for the sustainable development of arid and semi arid lands of Kenya. Nairobi: Office of the President, Special Programmes National.

ROK. (2008). Statistical abstract 2008. Nairobi: Kenya National Bureau Statistics (KBNS).

ROK. (2010). Proposed constitution of Kenya, 6th May 2010. Nairobi: Government Printers.

ROK. (2011, March 20). Weather Outlook for the March-May 2011 "Long-Rains” Season. Kenya Meteorological Department (KMD), Ministry of Environment and Mineral Resources. Daily Nation, p. 25.

Seo, S. N. (2010). Is an integrated farm more resilient against climate change? A micro-econometric analysis of portfolio diversification in African agriculture. Food Policy, 35(1), 32-40. http://dx.doi.org/10.1016/j.foodpol.2009.06.004

Silverman, D. (2004). Qualitative research: Theory, method and practice (Second Ed.). London: Sage Publishers.

Silverman, D. (2005). Doing qualitative research (Second Ed.). London: Sage Publishers.

Smucker, T. A., \& Wisner, B. (2008). Changing household responses to drought in Tharaka, Kenya: Vulnerability, persistence and challenge. Disasters, 32(2), 190-215. http://dx.doi.org/10.1111/j.14677717.2007.01035.x
Speranza, C. I. (2010). Drought coping and adaptation strategies: Understanding adaptations to climate change in agro-pastoral livestock production in Makueni district, Kenya. European Journal of Development Research, 22(5), 623-642. http://dx.doi.org/10.1057/ejdr.2010.39

United Nations Development Program [UNDP]. (2007). Human development report 2007/2008: Fighting climate change: Human solidarity in a divided world. New York: Palgrave Macmillan. http://dx.doi.org/10.1057/9780230598508

Vedwan, N., \& Rhoades, R. E. (2001). Climate change in the Western Himalayas of India: A study of local perception and response. Climate Research, 19(2), 109-117. http://dx.doi.org/10.3354/cr019109

Wardell, D. A., Reenberg, A., \& Tøttrup, C. (2003). Historical footprints in contemporary land use systems: Forest cover changes in savannah woodlands in the Sudano-Sahelian zone. Global Environmental Change, 13(4), 235-254. http://dx.doi.org/10.1016/S0959-3780(03)00056-6

West, C. T., Roncoli, C., \& Ouattara, F. (2008). Local perceptions and regional climate trends on the Central Plateau of Burkina Faso. Land Degradation and Development, 19(3), 289-304. http://dx.doi.org/10.1002/ldr.842

Wiesmann, U. (1998). Sustainable regional development in rural Africa: Conceptual framework and case studies from Kenya (Vol. A14). Berne, Switzerland: University of Berne Switzerland, Institute of Geography.

Wiesmann, U., Gichuki, F. N., Kiteme, B. P., \& Liniger, H. (2000). Mitigating conflicts over scarce water resources in the highland-lowland system of Mount Kenya. Mountain Research and Development, 20(1), 1015. http://dx.doi.org/10.1659/0276-4741(2000) 020\%5B0010:MCOSWR\%5D2.0.CO;2

Winarto, Y. T., Stigter, K., Anantasari, E., Prahara, H., \& Kristiyanto. (2010). We'll continue with our observations: Agro-meteorological learning in Indonesia. Farming Matters, 26(4), 12-15.

Winarto, Y. T., Stigter, K., Prahara, H., Anantasari, E., \& Kristiyanto. (2011). Collaborating on establishing an agro-meteorological learning situation among farmers in Java. Anthropological Forum, 21(2), 175197. http://dx.doi.org/10.1080/00664677. $\underline{2011.582836}$ 
World Bank. (2007). World development report 2008: Agriculture for development. Washington, D.C.: Author. http://dx.doi.org/10.1596/978-0-8213-6807-7

Ziervogel, G., Cartwright, A., Tas, A., Adejuwon, J., Zermoglio, F., Shale, M., \& Smith, B. (2008). Climate change and adaptation in African agriculture. Stockholm: Stockholm Environment Institute (SEI). Retrieved from http://www.seiinternational.org
Ziervogel, G., Nyong, A., Osman, B., Conde, C., Cortés, S., \& Downing, T. (2006). Climate variability and change: Implications for household food security (AIACC Working Paper No. 20). Washington, D.C.: Assessment of Impacts and Adaptations to Climate Change (AIACC). Retrieved from http://www.aiaccproject.org/ 